\title{
The Effect of Therapy of The Lower Urinary Tract Symptoms due to Prostatic Benign Enlargement on Erectile Function
}

1 Anja Štraus

1 Sandi Poteko

2 Andrej Starc

1 General hospital Celje, Celje, Slovenia

2 Faculty of Health Sciences, Department of Public Health, Slovenia, University of Ljubljana

\section{Abstract

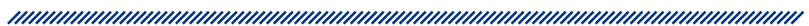

Background: Benign prostatic enlargement is the most common benign disease in men. The main cause for the emergence of benign prostatic enlargement is sexual hormone testosterone. Under the influence of enzyme 5-alpha reductase testosterone turns into active dihydrotestosterone, which is then combined with receptors and causes the growth of the prostate. Benign prostatic enlargement can cause the lower urinary tract symptoms. One of the treatment options of lower urinary tract symptoms due to benign prostatic enlargement is the treatment with medicaments - inhibitors 5-alpha reductase. Like any other medicament, this one can also have unpleasant side effects, between others reduced erectile function and reduced libido.

Methods: We used the International Index of Erectile Function (IIEF-5), Quality of Erection Questionnaire (QEQ), and demographic data.

Results: Men with benign prostatic enlargement have problems with keeping an erection even before starting the therapy with medicaments. After the therapy with inhibitors 5-alpha reductase the results of the research show that on the erectile function scale, there are no significant differences between the first and second measurement, but on the erectile dysfunction scale expected differences occur - the functionality decreases.
We also noticed that the independent variables of age and employment status have influence on the result of medicament treatment in the way that older participants in the study have more issues with erectile function than younger ones. Secondly, the men in retirement have more problem than employed men. There were no noticeable connections between the level of completed education and the profession of the participants.

Conclusions: The results of the research were expected, according to the previously consulted literature, where the side effects of treatment with medicaments inhibitors 5-alpha reductase were already mentioned. The effects that the treatment has on erectile function are that the function deteriorates, that is why it is important that we seek doctor assistance immediately after it occurs. The disease mainly manifests itself in older generation of men and it has a negative effect on erectile function already at the very beginning. Before starting the treatment the patients would need to be informed about the side effects of the medicament treatment and they should be presented other possibilities of treatment without side effects for erectile function.

Keywords: benign prostatic enlargement, erectile function, treatment with medicaments, lower urinary tract symptoms

Article received: 05.01.2020.

Article accepted: 15.02.2020.

https://doi.org/10.24141/1/6/1/8

Corresponding author:

Andrej Starc

Faculty of Health Sciences, Department of Public Health, University of Ljubljana

Zdravstvena pot 5, 1000 Ljubljana, Slovenia

E-mail: andrej.starc@guest.arnes.si 


\section{Introduction}

The prostate is a secondary male sexual organ situated between the bladder neck and outer sphincter muscle. The volume of the gland is approximately $25 \mathrm{~cm}^{3}$. Its main tasks are to produce a secretion, which is a part of the sperm liquid, and to store zinc (Zn). Zinc plays an antibacterial role and protects the prostate against inflammation. The prostate also significantly influences the quality of life of men in maturity and old age $\mathrm{a}^{1,2,3}$. In the process of ageing, the gland in the transitional zone grows by cell multiplication, which is why an adenoma grows and pushes the normal tissue to the edge of the prostate. The sexual hormone testosterone plays the primary role in this process. In the prostate, testosterone under the influence of 5-alpha reductase transfers to dihydrotestosterone, which then connects with receptors ${ }^{4}$.

Benign prostatic enlargement (BPE) is a medical term for prostate growth in old age. BPE is the most common disease in men and can cause lower urinary tract symptoms (LUTS). Although it is usually not a fatal disease, its symptoms can severely worsen the quality of a patient's life ${ }^{1}$. Tatt Foo ${ }^{5}$ describes BPE as a medical condition in which the abnormal enlargement of the gland at different levels of intensity can harm the bladder or kidneys, because it disrupts the flow of urine.

In his research, Lim $^{6}$ mentions a strong correlation between the disease, genetics, and unhealthy lifestyle (poor nutrition, lack of sport activities). The same risk factors for the emergence of BPE are mentioned in the work of Parsons ${ }^{7}$. He mostly connects BPE with age and genetic factors.

Patients with BPE can show lower urinary tract symptoms or no symptoms at all. If BPE starts to squeeze the urethra and move the side tissue, then it starts causing problems. It often happens that the enlarged prostate spreads away from the urethra area and it does not cause squeezing, which is why the patient shows no symptoms, even though the prostate has enlarged significantly. When the patient notices symptoms of the lower urinary tract, he needs to seek proper treatment ${ }^{4}$.

Trsinar divides the treatment according to the problems caused by urinating. If the patient has mild problems because of BPE, doctors only need to monitor the situation, make regular checks and suggest general preventive measures according to the patient's lifestyle. If the problems are mild, then treatment with medication should be started. When the problems do not cease even after medication and cause even more complications (bleeding, halting of urination, etc.) then the doctor will consider surgical treatment.

For the treatment of LUTS caused by BPE, 5-alpha reductase inhibitors (5ARI), inhibitors $\alpha$-1-adrenergic blockers (inhibitors $\alpha 1 \mathrm{AR}$ ), muscarinic receptor antagonist (MRA), $\beta 3$ (beta 3) adrenergic receptor agonist, herbal medications, or different combinations of drugs are used. Finasteride and dutasteride are parts of 5-alpha reductase inhibitors, and tamsoluzine is a part of $\alpha$-1-adrenergic blockers inhibitors ${ }^{8}$. The type of medication prescribed depends on the prostate volume. If the measured volume is between 25 and $40 \mathrm{~cm}^{3}$, the doctor will prescribe $\alpha$-1-adrenergic inhibitors, and if the volume is above $40 \mathrm{~cm}^{3}$, then 5 -alpha reductase inhibitors will be prescribed.

5-alpha reductase inhibitors are medications that affect the 5-alpha reductase enzyme. 5-alpha reductase changes testosterone into dihydrotestosterone, and if this process is impeded, then there is not enough dihydrotestosterone, which would make the prostate tissue grow. This medication decreases the volume of the prostate by $20-30 \%$, and the effect is seen after some time of therapy. The bigger the prostate is, the more effective this medication is. The effect of the drug can also be seen in lower concentrations of PSA in the blood. After 6 to 12 months of treatment, PSA in the blood is reduced by half ${ }^{8}$.

Kirk states that this type of therapy is safe and has minimal side effects ${ }^{9}$. Nevertheless, a few men mention erectile problems and other problems connected to libido. In most cases, when the therapy is stopped, the problems vanish.

Hoffman ${ }^{4}$ determined that these medications can have a side effect of the enlargement of breast tissue (gynecomastia). McVary and his colleagues ${ }^{10}$ observed the treatment with finasterides or combination therapy may lead to a decreased sexual desire and can cause worse erectile and ejaculation functions. Similar results are also found by Fwu and his team ${ }^{11}$, who state that both options of therapy lead to lower erectile function.

Erectile dysfunction (ED) or disruption of erection is the inability to get and hold an erection for satisfying sexual intercourse ${ }^{12}$. 


\section{Methodology}

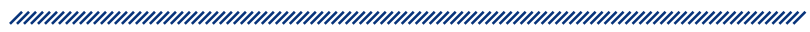

For this study, we used the International Index of Erectile Function (IIEF-5), the Quality of Erection Questionnaire (QEQ), and demographic data from the participants. The study was held in General Hospital Celje, in the urology department, in Slovenia. The study consists of two parts. The first part was from November 2017 to February 2018, in which time a questionnaire was given to the patients on their urology examination, with which we wanted to evaluate the state of their erectile function before starting the treatment with medication. The second part of the study was from May 2018 to August 2018, in which time the same questionnaire was given to the patients who came for an examination, after the start of the treatment. Fifty persons were invited to the study; all of them received the questionnaires.

First, the data were analysed with Microsoft Office Excel 2010. The nominal and ordinal variables were determined. After that, we used descriptive statistics and analysed the data with SPSS 22.0. We complied with statistical attribute at the value $p<0,05$.

After the first measurement of the entire sample, the distribution of both scales differed from normal distribution. On the scale of the repeated sample at the first and second measurements, only the QEQ scale differed from normal. We can also observe flatness from the asymmetric coefficients, as well as from the Kolmogorov-Smirnov test, which is not statistically typical. Because of the size of the sample and the abnormality of the data distribution, we will use non-parametric tests in continuation for testing our hypothesis (Table 1). To confirm the second hypothesis, we used a parametric regression test, because we observed a linear connection between two of the variables (i.e., age and employment status). With the help of regression, we also described the influence of these two variables on each other.

\section{Results}

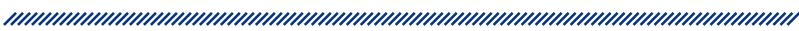

Fifty individuals participated in the first part of the study. They all differed in age, education level, employment status, and profession. The sample consisted solely of male participants. The majority of the sample ( $n=18 ; 36 \%$ ) was aged between 58 and 63 years and between 64 and 69 years $(n=18 ; 36 \%)$. There were few participants older than 70 years $n(=12 ; 24 \%)$, and the fewest $(n=2 ; 4 \%)$ were between 52 and 57 years old. There were no participants less than 52 years old.

The participants also differed in education level. The majority had completed secondary school education $(n=24 ; 48 \%)$. The same number of participants ( $n=8$; $16 \%$ ) had completed primary school education and tertiary education. A part of the participants did not complete high school $(n=4 ; 8 \%)$, the same percentages did not complete primary or higher education $(n=3 ; 6 \%)$.

The common average result of the IIEF-5 scale showed that the individuals had mild to moderate erectile dysfunction on average at the first measurement. The second measurement showed that the individuals on

\begin{tabular}{|c|c|c|c|c|c|c|c|c|}
\hline & \multirow[b]{2}{*}{$\mathrm{n}$} & \multirow[b]{2}{*}{ M } & \multirow[b]{2}{*}{ SD } & \multicolumn{2}{|c|}{ asymmetry } & \multicolumn{2}{|c|}{ Flatness } & \multirow{2}{*}{$\frac{\text { Kolmogorov-Smirnov }}{\mathrm{p}}$} \\
\hline & & & & As & $\mathrm{Se}$ & Spl & $\mathrm{Se}$ & \\
\hline \multicolumn{9}{|c|}{ 1. measurement } \\
\hline IIEF-5 & 50 & 13.98 & 7.19 & -0.77 & 0.34 & -0.30 & 0.66 & $0.03^{*}$ \\
\hline QEQ & 50 & 42.83 & 32.73 & -0.05 & 0.34 & -1.41 & 0.66 & $0.01^{*}$ \\
\hline \multicolumn{9}{|c|}{ 2. measurement } \\
\hline IIEF-5 & 31 & 11.58 & 7.21 & -0.01 & 0.42 & -0.86 & 0.82 & 0.20 \\
\hline QEQ & 31 & 34.54 & 32.88 & 0.39 & 0.42 & -1.04 & 0.82 & $0.00^{*}$ \\
\hline
\end{tabular}


average had moderate erectile dysfunction. The joint average result from QEQ scale showed that the quality of erection is better at first measurement in comparison to the second one, because the result is better on the scale from 0 to 100 . Next, we checked if the differences were statistically significant.

On the level of the entire sample, the distributions of both scales deviate from normal at the first measurement. On the level of the repeated sample, at the first and second measurements only, the QEQ scale deviates from normality. We also observed that in the coefficients of asymmetry and flatness and in the Kolmogorov-Smirnov test, which was not statistically common.

Because of the size of the sample and abnormality in the distribution of data, we used nonparametric tests for confirming the hypothesis.

\section{Discussion}

In the first part of the study, we had 50 participants. They all differed in age, education level, employment status, and profession. We only had male participants in the sample. The second part of the study consisted of 31 participants. All of them were a part of the first part.

The hypothesis: Men with LUTS caused by BPE have problems with erection prior to starting treatment with 5-alpha reductase inhibitors. After the treatment, erectile function worsens. The hypothesis showed that there are significant changes on the IIEF-5 scale; however, there are no statistically significant changes in the results on the QEQ scale. The results show that, based on the IIEF-5 questionnaire, the individuals have mild erectile dysfunction on average before starting the treatment with medication. This statement confirms our first hypothesis.

The expected result was that men with BPE had problems with keeping an erection before starting therapy with medication. We discovered that in the case of the IIEF-5 scale, with which we evaluated erectile dysfunction, there are noticeable differences between the first and second measurements. The patients claim even worse erectile function at the time of the second measurement. Based on the questionnaire QEQ, which measured the quality of erectile function, there were no significant differences between the first and second measurements.

Men with BPE had problems keeping an erection prior to starting the treatment with medications. After the treatment, there were no significant differences between measurements on the quality scale. However, there were noticeable differences on the scale of erectile dysfunction: functionality decreased severely.

The second hypothesis states that age, education level, profession, and employment status do not affect the outcome of treatment (5-alpha reductase inhibitors) of LUTS caused by BPE. First, we verified whether the independent variables have connections with the results of the first or second measurements, so that we could research the possible influence of individual variable.

Calculating the connectedness, we discovered that age has a significant connection with the results of the IIEF-5 scale ( $r=-0.48)$, and with results of the QEQ scale $(r=-0.38)$. The connection is negative, which means that individuals in older age group have lower results on both scales, which indicates worse erectile function at older patients. Other variables do not have significant connections with either of the scales.

At the second measurement, there are significant connections with results on the scales in the areas of age and employment status. The results were expected, because they again show that older patients have more problems with erections. At the same time, pensioners are reporting these issues more than employed individuals are.

As the therapy with medication showed some significant connections between erectile dysfunction, age and employment status, we checked, using regression, if these variables have some influence on the result itself.

Using multiple regression analysis, we checked if the demographic variables (age, education level, employment) had an impact on the result of the treatment of LUTS caused by BPE. The results of regression showed that $32 \%$ of variance IIEF- 5 test with demographical variables in which the predictor of employment status showed as statistically significant. In the case of the QEQ questionnaire, we can explain 29\% of the result variance with demographic variables, which also confirms the statistical importance of employment status. Based on employment status (employed or pensioner), we can predict the outcome of questionnaires IIEF-5 and QEQ, which show that pensioners are expected to have more problems. 


\section{Conclusions and recommendations}

The prostate is a very important organ in every man. It carries out multiple tasks and it is indispensable for various processes in the life of the individual ${ }^{13}$. In cases of diseases of the organ, medical treatment is inevitable. The doctor will then decide on the treatment, either with medication, operation or a combination of both. One common disease in older men is benign enlarged prostate, which can affect other organs and cause problems or medical conditions, such as lower urinary tract symptoms. Erectile dysfunction can also occur, which not only worsens the physical but also the psychological health of a patient ${ }^{14,15}$.

With analysis, we discovered that therapy with 5-alpha reductase inhibitors for healing LUTS caused by BPE affects erectile function. We also confirmed the hypothesis and answered the research questions. Even though the results were anticipated, we think they can be used in practice. The patients who are prescribed therapy with medication need to be informed about the risks. Opinions and research about this topic have previously appeared in the literature, also mentioning unwanted side effects, which demonstrate the significance of information for the patients. They need to be presented with the process of treatment and other therapy possibilities.

\section{References}

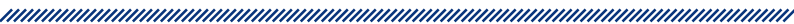

1. Tršinar B (2007). Benigna hiperplazija prostate. Novo mesto: Krka.

2. Urologija, d. o. o. (2017). Dostopno na: http://urologija. si/nekategorizirano/benigno-povecanje-prostate-bhp/ $<18$. 9. 2017>.

3. Boršnar S, Bratuš D, Čufer T (2016). Rak prostate. Ljubljana: Združenje urologov Slovenije: Onkološki inštitut: 6-7.

4. Hofmann R (1995). Prostataleiden: Was manner wissen sollten. 1. auflage. Baierbrunn: Wort und Bild Verlag, 16-100.

5. Tatt Foo K (2017). Pathophysiology of clinical benign prostatic hyperplasia. Asian J Urol 4(3): 152-57.

6. Lim KB (2017). Epidemiology of clinical benign prostatic hyperplasia. Asian J Urol 4(3): 148-51.

7. Parsons JK (2010). Benign prostatic hyperplasia and male lower urinary tract symptoms: epidemiology and risk factors. Curr Bladder Dysfunct Rep 5(4): 212-18.

8. Bizjak I, Bratuš D, Kmetec A in sod. (2014). Smernice za diagnostiko, spremljanje in zdravljenje moških s simptomi spodnjih sečil (SSS) zaradi benignega povečanja prostate (BPP). Združenje urologov Slovenije. Škofljiva: KAPRI- grafične storitve d.o.o..

9. Kirk D (2013). Težave s prostato. 1. izdaja. Ljubljana: eBesede d. o. o.

10. McVary KT, Rogers T, Mahon J, Gupta NK (2018). Is sexual function better preserved after water vapor thermal therapy or medical therapy for lower urinary tract symptoms due to benign prostatic hyperplasia? J Sex Med 15(12): 1728-38.

11. Fwu CW, Eggers PW, Kirkali Z, McVary KT, Burrows PK, Kusek JW (2014). Change in sexual function in men with lower urinary tract symptoms/benign prostatic hyperplasia associated with long-term treatment with doxazosin, finasteride and combined therapy. J Urol 191(6): 1828-34.

12. Hatzimouratidis K, Amar E, Eardley I et al. (2010). Guidelines on male sexual dysfunction: erectile dysfunction and premature ejaculation). Eur Urol 57(5): 804-14.

13. Bazar RM (2012). 10 Amazing Functions of the Prostate Gland. Men's Health. Dostopno na: https://prostate.net/ articles/10-amazing-functions-of-the-prostate-gland $<20.1 .2019>$.

14. Štrus B (2018). V skrbi za vaše zdravje: motnja erekcije. Krka, d. d., Novo mesto. Dostopno na: https://www.krka. biz/media/doc/si/vsvz/2016/3978_vsvz-erektilna-disfunkcija_internet.pdf <10. 9. 2018>.

15. Sand MS, Fisher W, Rosen R, Heiman J, Eardley I (2008). Erectile dysfunction and constructs of masculinity and quality of life in the multinational men's attitudes to life events and sexuality (MALES) Study. J Sex Med 5(3):583-94. 
82 Štraus A. et al. The Effect of Therapy of the Lower Urinary Tract Symptoms due to Prostatic Benign Enlargement... J. appl. health sci. 2020; 6(1): 77-82

\section{UTJECAJ LIJEČENJA SIMPTOMA DONJEG MOKRAĆNOG SUSTAVA UZROKOVANIH DOBROĆUDNIM POVEĆANJEM PROSTATE NA EREKTILNU FUNKCIJU}

\section{Sažetak}

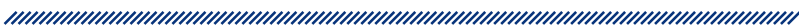

Uvod: Dobroćudno povećanje prostate je najčešća dobroćudna bolest u muškaraca. Glavni uzročnik pojave dobroćudnog povećanja prostate je muški spolni hormon testosteron. Pod utjecajem enzima 5-alfa reduktaze testosteron se pretvara u aktivni dihidrotestosteron, koji se tada kombinira s receptorima i uzrokuje rast prostate. Dobroćudno povećanje prostate može uzrokovati simptome u donjem mokraćnom sustavu. Jedna od mogućnosti liječenja simptoma donjeg dijela mokraćnog sustava uslijed dobroćudnog povećanja prostate je liječenje lijekovima - inhibitorima 5-alfa reduktaze. Kao i bilo koji drugi lijek, i ovaj može imati neugodne nuspojave, između ostalih smanjenu erektilnu funkciju i smanjeni libido.

Metode: Koristili smo međunarodni indeks erektilne funkcije (IIEF-5), upitnik o kvaliteti erekcije (QEQ) i demografske podatke.

Rezultati: Muškarci s benignim povećanjem prostate imaju problema s održavanjem erekcije, čak i prije nego što započnu terapiju lijekovima. Nakon terapije inhibitorom 5-alfa reduktaze rezultati istraživanja pokazuju da na ljestvici erektilne funkcije nema značajnih razlika između prvog i drugog mjerenja, ali na ljestvici erektilne disfunkcije dolazi do očekivanih razlika - funkcionalnost opada. Također smo primijetili da nezavisne varijable dobi i zaposlenja imaju utjecaj na rezultat liječenja lijekovima na način da stariji sudionici u istraživanju imaju više problema s erektilnom funkcijom od mlađih muškaraca. Zatim, muškarci u mirovini imaju više pro- blema nego muškarci koji su zaposleni. Nisu bile uočljive veze između završene razine obrazovanja i profesije sudionika.

Zaključci: Rezultati istraživanja bili su očekivani, prema prethodno konzultiranoj literaturi, gdje su već spomenute nuspojave liječenja inhibitorima 5-alfa reduktaze. Učinak koji tretman ima na erektilnu funkciju je pogoršanje funkcije, zato je važno potražiti pomoć liječnika odmah nakon što se pojavi. Bolest se uglavnom očituje kod starije generacije muškaraca i negativno utječe na erektilnu funkciju već u samom početku. Prije početka liječenja, pacijente bi trebalo informirati o nuspojavama liječenja lijekovima i treba im predstaviti druge mogućnosti liječenja bez nuspojava za erektilnu funkciju.

Ključne riječi: benigna proširenja prostate, erektilna funkcija, liječenje lijekovima, simptomi donjeg mokraćnog sustava 